\title{
ANALISIS LOAN TO DEPOSIT RATIO DAN NON PERFORMING LOAN PADA PT. BANK PERKREDITAN RAKYAT GEMA PESISIR AIR HAJI PESISIR SELATAN
}

\author{
Indra Oktaldi, Jhon Fernos \\ Akademi Keuangan dan Perbankan "Pembangunan" \\ indraoktaldi2018@gmail.com
}

\begin{abstract}
The purpose of this study is to determine the analysis of Loan to Deposit Ratio (LDR) and Non Performing Loans (NPL) at PT. Bank Perkreditan Rakyat Gema Pesisir Air Haji Pesisir Selatan. In analyzing the data, the authors used analysis data quantitative methods. Quantitative data is information data that is expressed in the form of figures from the measurement and calculation of the Loan To Deposit Ratio (LDR) and Non Performing Loan (NPL) analysis at PT. Bank Perkreditan Rakyat Gema Pesisir Cabang Air Haji Kabupaten Pesisir Selatan. The results of this study indicate that in the period 2018 - 2020 the Loan Deposit to Ratio (LDR) from the evaluation results is classified as healthy because the everages of value is $80,33 \%$ with the evaluation criteria matrix is in the position of $75 \%<L D R<100 \%$ and Non Performing Loans (NPL) evaluation results are classified as healthy because NPL $<5 \%$
\end{abstract}

Keywords: Bank, Loan To Deposit Ratio (LDR), Non Performing Loan (NPL)

\section{PENDAHULUAN}

Menurut Abdullah, (2014) Bank ialah lembaga keuangan yang memiliki peranan berguna dalam perbaikan sistem keuangan pendapatan masyarakat dan Negara. Menurut Purba \& Triaryati, (2018) Bank Perkreditan Rakyat merupakan lembaga keuangan bank yang melaksanakan kegiatan usaha secara konvensional atau berdasarkan Prinsip Syariah yang dalam kegiatannya tidak memberikan jasa dalam lalu lintas pembayaran. BPR hanya melakukan kegiatan berupa simpanan dalam bentuk deposito berjangka, tabungan, dan/atau bentuk lainnya yang dipersamakan dan menyalurkan dana sebagai usaha BPR. Dengan lokasi yang pada umumnya dekat dengan tempat masyarakat yang membutuhkan.

Menurut Syaifuddin (2018) Bank ialah salah satu lembaga yang menjadi penengah antara pihak yang kelebihan dana dan pihak yang kekurangan dana. Dana surplus adalah mereka yang memiliki dana lebih, dan dana tersebut kemudian disimpan di bank dalam bentuk giro, deposito berjangka dan tabungan. Sedangkan pihak yang kekurangan dana adalah pihak yang kekurangan dana, dan kekurangan dana tersebut dapat ditutup dengan meminjam ke bank.

Menurut Undang-Undang Nomor 10 Tahun 1998, kredit merupakan tagihan yang muncul diakibatkan oleh perjanjian pinjam meminjam yang terjadi diantara dua pihak (bank dengan calon nasabah) yang mana mewajibkan nasabah memenuhi kewajibannya berdasarkan waktu yang ditentukan beserta bunganya.sedangkan menurut Marlius, (2018) Menyatakan kredit merupakan 
penyediaan tagihan dan uang yang harus dibayar beserta bunganya oleh peminjam sesuai dengan kesepakatan yang telah disepakati dalam waktu tertentu.

Laporan keuangan adalah dua agenda yang ditetapkan oleh pemegang buku di akhir kerangka waktu organisasi. Kedua catatan ini adalah laporan penurunan nilai aset atau penurunan nilai mata uang dan penurunan nilai atau penurunan nilai pembayaran. Selain itu, menggambarkan situasi mata uang dalam kelompok pada waktu tertentu (Afriyeni \& Fernos, 2018).

Menurut Wiagustini, (2014) Loan To Deposit Ratio (LDR) adalah rasio antara besarnya seluruh volume kredit yang disalurkan oleh bank dan jumlah penerimaan dana dari berbagai sumber. Sedangkan menurut Afriyeni, A \& Fernos, (2018) Loan To Deposit Ratio (LDR) merupakan jenis rasio yang digunakan untuk mengukur sejauh mana kemampuan bank dalam memenuhi kewajiban yang bersifat jangka pendek (liquiditas) dengan cara membagi total jumlah kredit terhadap total dana pihak ketiga (DPK).

Menurut Agustiningrum, (2013) Non Performing Loan (NPL) adalah alat ukur dari bank untuk menunjukkan risiko debitur yang tidak mampu membayarkan hutangnya sesuai dengan waktu yang dijanjikan. Kredit bermasalah muncul dikarenakan tidak lancarnya pengembalian pinjaman beserta bunga dari debitur. Akibatnya dapat menurunkan kinerja bank sehingga perusahaan menjadi tidak efisien.

PT. Bank Perkreditan Rakyat Merupakan lembaga keuangan perbankan yang melakukan kegiatan usaha secara tradisional atau berdasarkan prinsip syariah, dan tidak memberikan jasa arus pembayaran dalam kegiatannya. BPR hanya melakukan kegiatan dalam bentuk simpanan tetap, tabungan dan/atau bentuk simpanan lainnya yang dipersamakan dengan itu, dan mengalokasikan dana sebagai usaha BPR. Lokasinya biasanya dekat dengan masyarakat yang membutuhkan.

Berikut ini hasil Data Total Kredit Yang Diberikan, Dana Pihak Ketiga Dan Kredit Bermasalah pada PT. Bank Perkreditan Rakyat Gema Pesisir Cabang Air Haji Kabupaten Pesisir Selatan periode 2018-2020

\section{Tabel 1}

Data Total Kredit Yang Diberikan, Dana Pihak Ketiga Dan Kredit Bermasalah Pada PT. Bank Perkreditan Rakyat Gema Pesisir

Periode 2018 - 2020

(dalam Rp.000)

\begin{tabular}{cccc}
\hline Tahun & $\begin{array}{c}\text { Jumlah Pinjaman } \\
\text { Yang diberikan }\end{array}$ & $\begin{array}{c}\text { Jumlah Dana } \\
\text { Pihak Tiga }\end{array}$ & $\begin{array}{c}\text { Jumlah Kredit } \\
\text { Bermasalah }\end{array}$ \\
\hline 2018 & 50.369 .156 & 61.824 .234 & 785.759 \\
2019 & 57.320 .538 & 69.288 .334 & 1.215 .196 \\
2020 & 59.510 .257 & 75.536 .262 & 928.360
\end{tabular}

Sumber: PT. Bank Perkreditan Rakyat Gema Pesisir

Berdasarkan Tabel 1 di atas, dapat diketahui bahwa Loan To Deposit Ratio (LDR) mengalami peningkatan dari tahun 2018 sampai dengan 2020 berdasarkan total kredit yang diberikan dan total dana pihak ketiga (DPK). Begitu dengan Non 
Performing Loan (NPL) mengalami peningkatan dari tahun 2018 sampai dengan 2019, sedangkan dengan tahun 2020 mengalami penurunan.

\section{METODE PENELITIAN}

\section{Metode Pengumpulan Data}

Metode pengumpulan data dapat dilakukan dengan dua cara yaitu :

a. Studi Kepustakaan (Library Research)

Studi kepustakaan merupakan kegiatan dalam memperoleh informasi yang signifikan sesuai dengan masalah objek penelitian yang diperoleh dari mempelajari buku-buku, karya ilmiah, internet, dan sumber lainnya.

b. Studi Lapangan (Field Research)

Studi lapangan merupakan pengamatan secara langsung di lokasi kegiatan yang dilandasi pengalaman dan pengetahuan secara teoritis dalam menggali dan mengumpulkan objek yang diteliti berupa data, serta melakukan penyusunan data/informasi yang diperoleh guna sebagai pemecahan masalah laporan keuangan.

\section{Metode Analisa Data}

Pada analisis data, penulis menggunakan data kuantitatif sebagai metode penelitian, dimana metode kuantitatif tersebut kegiatannya adalah mencari data berupa angka-angka selama kegiatan penelitian berlangsung. Dalam metode ini penulis menjelaskan data secara fakta yang dialami sesuai dengan teori yang ada. Analisis ini digunakan untuk mengukur tingkat kesehatan bank berdasarkan analisis rasio Loan to Deposit Ratio (LDR) dan Non Performing Loan (NPL) pada PT. Bank Perkreditan Rakyat Gema Pesisir Cabang Air Haji Kabupaten Pesisir Selatan

\section{HASIL DAN PEMBAHASAN \\ Pengertian Bank}

Menurut Putri \& Marlius, (2020) Bank merupakan lembaga keuangan, yang berperan dalam berkontribusi terhadap pembagunan ekonomi pada suatu Negara. Dari pengertian sebelumnya maka dapat disimpulkan pengertian bank ialah suatu badan keuangan yang dibawah naugan Undang-undang suatu Negara berkekuatan hukum, sehingga pihak bank diwajibkan mematuhi dan mengikuti peraturan yang telah ditetapkan.

\section{Pengertian Laporan Keuangan}

Menurut Mirza, (2019) Laporan Keuangan (financial statement) merupakan suatu gambaran dari suatu perusahaan pada waktu tertentu biasanya satu periode akuntansi dan memberikan gambaran tentang kondisi keuangan yang dicapai perusahaan pada waktu tertentu.

\section{Pengertian Kinerja Keuangan}

Menurut Munawir, (2014) Pengertian Kinerja Keuangan Menurut munawir, (2014) kinerja keuangan perusahaan merupakan suatu gambaran tentang kondisi keuangan suatu perusahaan yang dianalisis dengan alat-alat analisis keuangan, sehingga dapat diketahui mengenai baik buruknya keadaan keuangan 
suatu perusahaan yang mencerminkan pencapaiannya. Perusahaan dalam operasinya dalam jangka waktu tertentu.

\section{Pengertian Bank Perkreditan Rakyat ( BPR)}

PT. Bank Perkreditan Rakyat adalah lembaga keuangan bank yang melaksanakan kegiatan usaha secara konvensional atau berdasarkan Prinsip Syariah yang dalam kegiatannya tidak memberikan jasa dalam lalu lintas pembayaran. BPR hanya melakukan kegiatan berupa simpanan dalam bentuk deposito berjangka, tabungan, dan/atau bentuk lainnya yang dipersamakan dan menyalurkan dana sebagai usaha BPR. Dengan lokasi yang pada umumnya dekat dengan tempat masyarakat yang membutuhkan.

\section{Pengertian Kredit}

Kredit merupakan salah satu fungsi bank untuk meringankan permasalahan masyarakat umum dalam memenuhi kebutuhan hidupnya. Menurut Undang-undang no 10 tahun 1998 kredit merupakan tagihan yang muncul diakibatkan oleh perjanjian pinjam meminjam antara bank dengan calon nasabah yang mana mewajibkan pihak nasabah melunasi utangnya sesuai waktu tertentu beserta bunganya. Dalam mengembalikan kredit apabila nasabah terlambat atau tidak tepat waktu, maka akan dikenakan sanksi berupa denda.

\section{Pengertian Loan To Deposit Ratio (LDR)}

Menurut Kasmir, (2014) (LDR) merupakan jenis rasio yang digunakan untuk mengukur jumlah kredit yang diberikan dengan jumlah modal sendiri dan modal lainnya yang digunakan. Artinya rasio ini mengukur sejauh mana kesanggupan perbankan dalam memenuhi tanggung jawab utang jangka pendeknya dengan aset yang dimilikinya. Batas aman dari penilaian LDR suatu bank adalah sekitar 75\%, namun batas maksimalnya adalah 100\%. Rasio ini dihitung dengan membandingkan total jumlah kredit dengan total dana dari pihak ketiga (DPK), dan tidak termasuk kredit yang diberikan kepada pihak lain. Sedangkan pihak ketiga menghimpunkan dananya melalui giro, tabungan dan deposito berjangka yang tidak termasuk antar bank.

Rasio pinjaman terhadap simpanan (LDR) dapat dirumuskan sebagai berikut

(Surat Edaran Bank Indonesia No. 3/30 DPNP tanggal 14 Desember 2001:

$$
L D R=\frac{\text { Total Kredit yang Diberikan }}{\text { Total Dana Pihak Ketiga }} \times 100 \%
$$

Bank Indonesia akan menetapkan rasio pinjaman terhadap simpanan (LDR) sesuai dengan Surat Edaran BI No. 13/24 DPNP tanggal 25 Oktober 2011. Berdasarkan sumber Bank Indonesia rasio pinjaman terhadap simpanan (LDR) adalah sebagai berikut:

Tabel 2

Kriteria Penilaian Loan To Deposit Ratio (LDR)

\begin{tabular}{ccc}
\hline No & Rasio & Kriterian Penilaian \\
\hline 1 & LDR $<75 \%$ & Sangat Sehat \\
2 & $75 \%<\mathrm{LDR} \leq 85 \%$ & Sehat \\
3 & $85 \%<\mathrm{LDR}<100 \%$ & Cukup Sehat \\
4 & $100 \%<\mathrm{LDR} \leq 120 \%$ & Tidak Sehat \\
5 & $\mathrm{LDR}>120 \%$ & Sangat Tidak Sehat \\
\hline
\end{tabular}

Sumber: surat edaran BI No. 6/23/DPNP tahun 2004 
Dari table 3.1 diatas dapat dilihat bahwa kriteria penilaian LDR yang mana batas aman yaitu $75 \%$ dan batas maksimal LDR $100 \%$. Jika LDR berada dibawah 75\% itu tidak baik bagi bank hal tersebut disebabkan karena jika terlalu banyak dana yang mengendap maka dapat menyebabkan bank merugi, sedangkan kalau LDR melewati batas maksimal yaitu di atas $100 \%$ maka dapat menyebabkan semakin rendah kemampuan likuiditas bank hal ini disebabkan karena jumlah dana yang diperlukan untuk membiayai kredit sangat tinggi sementara dana yang tersedia tidak mencukupi.

\section{Analisis Loan To Deposit Ratio (LDR)}

Menurut Herman Darmawai (2017) Non Performing Loan (NPL) adalah kredit bermasalah yang diakibatkan oleh ketidak lancaran pembayaran pokok pinjaman dan bunga yang secara langsung dapat menurunkan kinerja bank dan menyebabkan bank tidak efisien.

Rasio pinjaman terhadap simpanan (LDR) dapat dirumuskan sebagai berikut (Surat Edaran Bank Indonesia No. 3/30 DPNP tanggal 14 Desember 2001:

$$
L D R=\frac{\text { Total kredit yang diberikan }}{\text { Dana pihak ketiga }+ \text { Modal }} \times 100 \%
$$

Berdasarkan data yang diperoleh melalui rasio pinjaman terhadap simpanan PT. Tabel berikut menunjukkan Bank Perkreditan Rakyat Gema Pesisir Air Haji Pesisir Selatan dari Desember 2018 hingga Desember 2020

\section{Tabel 3}

Kriteria Penilaian Loan To Deposit Ratio (LDR)

PT. Bank Perkreditan Rakyat Gema Pesisir Air Haji Pesisir Selatan Periode 2018-2020

(dalam Rp.000,-)

\begin{tabular}{ccccc}
\hline No & Tahun & $\begin{array}{c}\text { Jumlah Kredit } \\
\text { Yang Diberikan }\end{array}$ & $\begin{array}{c}\text { Dana Pihak } \\
\text { Ketiga }\end{array}$ & $\begin{array}{c}\text { Loan Deposit to Ratio (LDR) } \\
(\mathbf{1 : 2}) \times \mathbf{1 0 0} \%\end{array}$ \\
\hline 1 & 2018 & 50.369 .156$. & 61.824 .234 & $81 \%$ \\
2 & 2019 & 57.320 .538 & 69.288 .334 & $82 \%$ \\
3 & 2020 & 59.510 .257$. & 75.536 .262 & $78 \%$ \\
\hline
\end{tabular}

Sumber:PT. BPR Gema Pesisir, Data Diolah

Analisis Non Performing Loan (NPL)

Non Performing Loan (NPL) Jika merupakan debitur atau sekelompok debitur yang tergolong Wajar Tanpa Pengecualian dan mencurigakan kerugian akibat peringkat kreditnya, perlu diingat bahwa perubahan klasifikasi kredit dari kredit lancar menjadi kredit bermasalah (NPL) diharapkan terjadi. melewati proses penurunan kualitas kredit. Salah satu risiko yang ditimbulkannya adalah aktivitas perbankan yang semakin kompleks menimbulkan konsekuensi yang lebih besar. Dengan kata lain, semakin besar skala operasional bank, semakin rendah tingkat pengawasannya, sehingga kredit bermasalah (NPL) akan semakin besar, atau risiko kreditnya juga akan semakin besar (Afriyeni \& Fernos, 2018)

Kredit bermasalah (NPL) adalah kredit bermasalah yang merupakan indikator untuk menilai kualitas kinerja bank. Artinya Non Performing Loan (NPL) menandakan bahwa bank tersebut bermasalah. Apabila solusi tidak segera 
diperoleh maka akan berdampak negatif bagi bank. Apabila kredit bermasalah (NPL) terus meningkat maka akan berdampak negatif bagi perbankan.

Untuk menilai bank terhadap rasio NPL, maka Bank Indonesia menetapkan kriteria rasionya sesuai tabel dibawah ini:

\section{Tabel 4}

Kriteria Penilaian Tingkat Kesehatan Non Performing Loan (NPL)

\begin{tabular}{cc}
\hline Predikat & Rasio \\
\hline Sehat & NPL $<5 \%$ \\
Tidak Sehat & NPL $>5 \%$
\end{tabular}

Sumber : Bank Indonesia

Peraturan Bank Indonesia Nomor 17 / II / PBI Tahun 2015 mengatur bahwa rasio kredit bermasalah (NPL) adalah 5\%, dan rumus perhitungan kredit bermasalah (NPL) adalah sebagai berikut:

$$
N P L=\frac{\text { Total Kredit Bermasalah }}{\text { Total Kredit }} \times 100 \%
$$

Berdasarkan data yang diperoleh penulis, tabel berikut digunakan untuk menghitung kredit bermasalah (NPL) PT. BPR Gema Pesisir Air Haji Pesisir Selatan dari Desember 2018 hingga Desember 2020:

\section{Tabel 5}

Perhitungan Non Performing Loan (NPL) PT. Bank Perkreditan Rakyat Gema Pesisir Cabang Air Haji Kabupaten Pesisir Selatan

Tahun 20182020

( dalam Rp. 000,- )

\begin{tabular}{ccrcc}
\hline No & Tahun & $\begin{array}{c}\text { Jumlah Non } \\
\text { Performing Loan } \\
\text { (NPL ) }\end{array}$ & $\begin{array}{c}\text { Jumlah } \\
\text { Kredit }\end{array}$ & $\begin{array}{c}\text { Non Performing } \\
\text { Loan (NPL ) (1:2) } \\
\text { x100\% }\end{array}$ \\
\hline 1 & 2018 & 785.759 & 50.369 .156 & 1,56 \\
2 & 2019 & 1.215 .196 & 57.320 .538 & 2,12 \\
3 & 2020 & 928.360 & 59.510 .257 & 1,56 \\
\hline
\end{tabular}

Sumber: PT. BPR Gema Pesisir, Data Diolah

Setelah dilakukan perhitungan analisis, maka dapat dilihat perbandingan rasio keuangan selama tiga tahun terakhir. Berikut ini adalah penjelasannya sesuai dengan tabel dibawah:

Tabel 6

Evaluasi Rata-Rata Industri

PT. Bank Perkreditan Rakyat Gema Pesisir Air Haji Pesisir Selatan

Periode 2018-2020

\begin{tabular}{cccccccc}
\hline Rasio & $\begin{array}{c}\text { Rata- } \\
\text { Rata } \\
\text { Industri }\end{array}$ & $\begin{array}{c}\text { Tahun } \\
\mathbf{2 0 1 8}\end{array}$ & Evaluasi & $\begin{array}{c}\text { Tahun } \\
\mathbf{2 0 1 9}\end{array}$ & Evaluasi & $\begin{array}{c}\text { Tahun } \\
\mathbf{2 0 2 0}\end{array}$ & Evaluasi \\
\hline LDR & $<110 \%$ & $81 \%$ & $\begin{array}{c}\text { Cukup } \\
\text { Sehat }\end{array}$ & $82 \%$ & $\begin{array}{c}\text { Cukup } \\
\text { Sehat }\end{array}$ & $78 \%$ & Cukup \\
& & & Sehat & $2,12 \%$ & Sehat & $1,56 \%$ & Sehat \\
\hline NPL & $<5 \%$ & $1,56 \%$ & Sehat &
\end{tabular}

Sumber:http//www.ojk.go.id, Data olahan 
Berdasarkan tabel 6 terlihat pada periode 2018 - 2020 dimana tingkat rasio pinjaman yang diberikan atau Loan Deposit to Ratio (LDR) PT. Bank Perkreditan Rakyat Gema Pesisir Gema Pesisir Cabang Air Haji Kabupaten Pesisir Selatan dari hasil evaluasi tergolong cukup sehat karena LDR $<100 \%$ dengan matriks kriteria penilaian berada posisi $>75 \%-\leq 85 \%$ ( cukup sehat ). Ini membuktikan PT. Bank Perkreditan Rakyat Gema Pesisir Cabang Air Haji Kabupaten Pesisir Selatan tidak mengalokasikan seluruh dana, termasuk aset lancar dan dana milik sendiri yang memiliki cadangan dan harus segera dibayarkan. Semakin tinggi nilai Loan To Deposit Ratio (LDR) maka tingkat likuiditas bank semakin rendah, begitu pula sebaliknya semakin rendah nilai Loan Deposit to Ratio (LDR), maka tingkat likuiditas akan tinggi

Untuk kredit bermasalah atau Non Performing Loan (NPL) pada tabel 6 terlihat pada periode 2018 - 2020 PT. Bank Perkreditan Rakyat Gema Pesisir Cabang Air Haji Kabupaten Pesisir Selatan dari hasil evaluasi tergolong sehat karena NPL < $5 \%$ Ini artinya semakin kecil nilai Non Performing Loan (NPL), maka tingkat profitabilitas bank akan meningkat sebaliknya, menjadi lebih besar Non Performing Loan ( NPL ), maka tingkat profitabilitas akan mengalami penurunan.

\section{SIMPULAN}

Berdasarkan analisis perhitungan rasio keuangan bahwa penelitian dapat disimpulkan Sebagai berikut :

Loan To Deposit Ratio pada PT. Bank Perkreditan Rakyat Gem Pesisir Air Haji Kabupaten Pesisir Selatan. Pada periode 2018 - 2020 mengalami naik turun sebesar 81\%, 82\%, 78\%, artinya Bank Perkreditan Rakyat selama tiga tahun terakhir termaksuk cukup sehat. Dimana Loan To Deposit Ratio (LDR) berdasarkan standar kriteria Bank Indonesia tidak melampaui batas maksimum yaitu $<100 \%$. Ini membuktikan bahwa bank mampu mengelola likuiditas dalam menghimpunkan dana dan memberikan pinjaman kepada debitur dengan baik sedangkan Non Performing Loan (NPL) periode 2018 - 2020 dengan persentase berturut-turut 1,56\%,2,12\%, 1,56\% sesuai dengan kriteria ketentuan Bank Indonesia yaitu NPL $<5 \%$, artinya bank dalam keadaan sehat. Ini membuktikan bahwa bank mampu mengelola kredit dengan baik sehingga dapat memberikan pinjaman kepada masyarakat.

\section{UCAPAN TERIMA KASIH}

Penulis mengucapkan terima kasih kepada PT. Bank Perkreditan Rakyat Gema Pesisir Air Haji Pesisir Selatan yang telah mengizinkan dan membantu penulis dalam memperoleh informasi. Serta semua pihak yang telah membantu penulis dalam penyelesaian artikel ini.

\section{DAFTAR PUSTAKA}

Abdullah, 2009. (2014). Analisis Pengaruh Pembiayaan Mudharabah Dan Musyarakah Terhadap Tingkat Profitabilitas (Return On Equity) (Studi pada Bank Umum Syariah Yang Terdaftar di Bank Indonesia Periode 2009-2012). Jurnal Administrasi Bisnis S1 Universitas Brawijaya, 12(1), 83022. 
Afriyeni, A., \& Fernos, J. (2018). Analisis Faktor-Faktor Penentu Kinerja Profitabilitas Bank Perkreditan Rakyat (BPR) Konvensional Di Sumatera Barat. Jurnal Benefita, 3(3), 325. https://doi.org/10.22216/jbe.v3i3.3623

Agustiningrum, R. (2013). Analisis Pengaruh CAR, NPL, Dan LDR Terhadap Profitabilitas Pada Perusahaan Perbankan. E-Jurnal Manajemen Universitas Udayana, 2(8), 255030.

Herman Darmawai ( 2011). (2017). Pengaruh Makroekonomi Terhadap Non Performing Loan (NPL) Di Indonesia: Studi Non Performing Loan Perbankan. Jurnal Ekonomi Dan Kebijakan Publik, 7(2), 159. https://doi.org/10.22212/jekp.v7i2.669

Amelia, L., \& Marlius, D. (2018). Pengendalian Kredit Dalam Upaya Menciptakan Bank Yang Sehat Pada PT. Bank Pembangunan Daerah Sumatera Barat Cabang Utama Padang. 2007, 1-11. https://doi.org/10.31227/osf.io/kpc64

Mirza, M., \& Afriyeni, A. (2019). Analisis Rasio Rentabilitas Pada PT. Bank Pembangunan Daerah (BPD) Sumatera Barat Cabang Utama Padang. 10, 1-11. https://doi.org/10.31219/osf.io/5mq98

Purba, P. L., \& Triaryati, N. (2018). Pengaruh CAR, NPL, BOPO,dan LDR Terhadap Net Interst Margin Pada Perusahaan Perbankan Yang Terdaftar di BEI. E-Jurnal Manajemen Unud, 7(1), 387-411.

Putri, D. M., \& Marlius, D. (2020). Analisis Rasio Profitabilitas Pada PT Bank Perkreditan Rakyat Lugas Dana Mandiri Padang. 1-10. https://osf.io/preprints/kaw2e/

Syaifuddin, F., Rio, S., Sarita, B., Syaifuddin, D. T., Saleh, S., Hamid, W., \& Budi, N. (2018). Effect Of Equity To Assets Ratio ( EAR ), Size, And Loan To Assets Ratio ( LAR ) On Bank Performance Fahrul Puas Sriawan Rio Prabowo Halim Buyung Sarita Dedy Takdir Syaifuddin Sujono Salma Saleh Wahyuniati Hamid. 9(4), 1-6.

Undang-undang No 10 Tahun 1998 Tentang Perubahan Undang-undang No 7 Tahun 1992. (2019). Berdasarkan Undang-undang Nomor 10 Tahun 1998 Tentang Perubahan Atas Undang-undang Nomor 7 Tahun 1992 Tentang Perbankan. Jurnal Hukum Positum, 4(2), 1. https://doi.org/10.35706/positum.v4i2.3179

Wiagustini, \& Wiagustini, N. L. P. (2014). Pengaruh Dana Pihak Ketiga , Non Performing Loan, Dan Capital Adequacy Ratio Terhadap Loan To Deposit Ratio Dan Return On Assets Pada Sektor Perbankan Di Bursa Efek Indonesia. E-Jurnal Ekonomi Dan Bisnis Universitas Udayana, 11(3), 650673. 